\title{
Light Scattering by Particles: Computational Methods
}




\section{ADVANCED SERIES IN APPLIED PHYSICS}

Volume 1: Optical Effects Associated with Small Particles

edited by P. W. Barber \& R. K. Chang

Volume 2: Light Scattering by Particles: Computational Methods

by P. W. Barber \& S. C. Hill 


\section{ADVANCED SERIES IN APPLIED PHYSICS}

\section{Light Scattering by Particles: \\ Computational Methods}

\section{P W BARBER S C HILL}

Clarkson University 
Published by

World Scientific Publishing Co. Pte. Ltd.

P O Box 128, Farrer Road, Singapore 912805

USA office: Suite 1B, 1060 Main Street, River Edge, NJ 07661

UK office: 57 Shelton Street, Covent Garden, London WC2H 9HE

\section{British Library Cataloguing-in-Publication Data}

A catalogue record for this book is available from the British Library.

First published 1990

First reprint 1998

\section{LIGHT SCATTERING BY PARTICLES: COMPUTATIONAL METHODS}

Copyright $@ 1990$ by World Scientific Publishing Co. Pte. Ltd.

All rights reserved. This book, or parts thereof, may not be reproduced in any form or by any means, electronic or mechanical, including photocopying, recording or any information storage and retrieval system now known or to be invented, without written permission from the Publisher.

For photocopying of material in this volume, please pay a copying fee through the Copyright Clearance Center, Inc., 222 Rosewood Drive, Danvers, MA 01923, USA. In this case permission to photocopy is not required from the publisher.

ISBN 9971-50-813-3

ISBN 9971-50-832-X (pbk)

Printed in Singapore. 


\section{Preface}

This book presents the separation-of-variables and T-matrix methods of calculating the scattering of electromagnetic waves by particles. Analytical details and computer programs are provided for determining the scattering and absorption characteristics of the finite-thickness slab, infinite circular cylinder (normal incidence), general axisymmetric particle, and sphere. The methods and programs are applicable to electromagnetic wave scattering in general. However, the calculated results emphasize light scattering, e.g., the intensity is displayed rather than the electric field.

The computer programs are designed to generate data that is easy to graph and visualize, and test cases in the book illustrate the capabilities of the programs. The connection between the theory and the computer programs is reinforced by references in the computer programs to equations in the text. This cross-referencing will help the reader understand the computer programs, and, if necessary, modify them for other purposes.

The basic theoretical background as well as the documented and tested computer programs should be a useful reference for individuals who are new to the light scattering field as well as those with more experience. The book may also be useful as a supplement to a graduate level course.

While the computer programs have been tested for a variety of cases, it is not inconceivable that a particular program contains errors. Also, input parameters can be used which are outside the envelope of values for which results are computed accurately. Furthermore, especially with the T-matrix programs, it is possible to generate incorrect results if the convergence testing procedures are not carefully 
vi Preface

followed. For these reasons, the authors and publisher disclaim all liability for any damages that may result from the use of the programs.

The programs are copyrighted, but each purchaser of this book is free to make copies of the source codes as required for their needs. We believe that the computer programs included with the book should be used in the same way as the text portion-only a single person should use them at any given time.

We acknowledge the contributions of former students Dau-Sing Y. Wang, Chun-Hong Chen, Pamela E. Geller, Barbara E. Messinger and Daniel S. Benincasa. Professor Milton Kerker of Clarkson University has nurtured our interest in light scattering and was among the first to appreciate the role that computer calculations can play in light scattering research. Professor Richard K. Chang of Yale University has provided continuous encouragement. The innovative experiments performed by him and his colleagues have been the primary motivation for developing many of the computer programs.

It would have been difficult to create this book without the $\mathrm{T}_{\mathrm{EX}}$ document preparation and typesetting system or the graphics programs developed by Golden Software, Inc. (Golden, Colorado). The entire manuscript was carefully typeset (using $\mathrm{T}_{\mathrm{E}} \mathrm{X}$ ) and made camera-ready by Ms. Elizabeth Hernandez, to whom we are exceedingly grateful. 


\section{Contents}

Preface

Chapter 1

INTRODUCTION

$1.1 \quad$ LIGHT SCATTERING BY PARTICLES

1.2 TIME-HARMONIC ELECTROMAGNETIC PLANE WAVES

1.3 SCATTERING OF A PLANE WAVE BY A SLAB

1.4 SCATTERING PARAMETERS AND FEATURES

1.5 ASSUMPTIONS AND LIMITATIONS

1.5.1 Particles

1.5.2 Incident Fields

1.6 COMPUTER PROGRAMS

1.7 SAMPLE COMPUTER PROGRAM

REFERENCES 
viii Contents

Chapter 2

SCATTERING BY AN INFINITE CIRCULAR CYLINDER AT NORMAL INCIDENCE

2.1 SEPARATION OF VARIABLES SOLUTION 26

$\begin{array}{lll}2.1 .1 & \text { TM Polarization } & 26\end{array}$

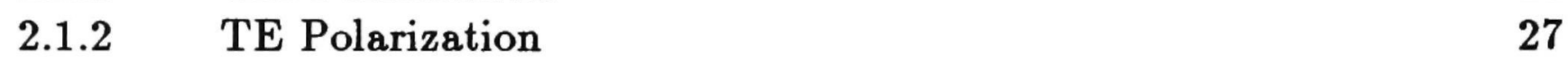

$\begin{array}{lll}2.1 .3 & \text { Scattered Intensity and Efficiencies } & 28\end{array}$

$2.2 \quad$ NUMERICAL IMPLEMENTATION 29

$\begin{array}{lll}2.2 .1 & \text { Computer Program Description } & 29\end{array}$

2.2.2 Computational Procedures and Convergence Considerations 30

$\begin{array}{lll}2.3 & \text { ANGULAR SCATTERING } & 32\end{array}$

$\begin{array}{lll}2.4 & \text { SPECTRAL SCATTERING } & \mathbf{3 6}\end{array}$

$2.5 \quad$ INTENSITY DISTRIBUTIONS

2.5.1 Angle-Averaged Intensity $\quad 47$

$\begin{array}{lll}\text { 2.5.2 Surface Intensity } & 50\end{array}$

2.5.3 Internal Intensity Distribution $\quad 53$

2.5.4 External Intensity Distribution 58

2.6 AUXILIARY COMPUTER PROGRAMS 62

2.6.1 Small-Particle Approximation $\quad 64$

$\begin{array}{lll}\text { 2.6.2 Program Dimensions } & 68\end{array}$

$2.7 \quad$ SAMPLE COMPUTER PROGRAM 68

$\begin{array}{ll}\text { REFERENCES } & 77\end{array}$ 
Chapter 3

SCATTERING BY AXISYMMETRIC PARTICLES

T-MATRIX METHOD

$\begin{array}{lll}3.1 & \text { T-MATRIX METHOD } & 79\end{array}$

$\begin{array}{lll}3.1 .1 & \text { General Formulation } & 79\end{array}$

$\begin{array}{lll}3.1 .2 & \text { Internal Field } & 82\end{array}$

$\begin{array}{lll}\text { 3.1.3 } & \text { Scattered Field } & 85\end{array}$

$\begin{array}{lll}\text { 3.1.4 Scattered Intensity and Efficiencies } & 88\end{array}$

$\begin{array}{lll}3.1 .5 & \text { Surface Integrals } & 89\end{array}$

3.2 NUMERICAL IMPLEMENTATION 92

3.2.1 Computer Program Description $\quad 93$

3.2.2 Coordinate Transformation 94

3.2.3 Computational Procedures and Convergence Considerations 101

3.3 ANGULAR SCATTERING

PARTICLES IN A FIXED ORIENTATION 109

$\begin{array}{lll}\text { 3.3.1 Scattering Over a Plane } & 109\end{array}$

$\begin{array}{ll}\text { 3.3.2 } & \text { Scattering in All Directions } \\ \end{array}$

3.4 ANGULAR SCATTERING

PARTICLES IN RANDOM ORIENTATION 115

3.4.1 Particles Randomly Oriented in Two Dimensions 116

3.4.2 Particles Randomly Oriented in Three Dimensions 121

$\begin{array}{lll}\text { 3.4.3 Scattering Matrix } & 125\end{array}$

$\begin{array}{lll}3.5 & \text { SPECTRAL SCATTERING } & 131\end{array}$

3.5.1 Fixed Orientation 131

3.5.2 Random Orientation 132

$\begin{array}{ll}\text { 3.6 INTENSITY DISTRIBUTIONS } & \mathbf{1 3 5}\end{array}$

$\begin{array}{lll}\text { 3.6.1 Internal Intensity Distribution } & 137\end{array}$

$\begin{array}{ll}\text { 3.6.2 External Intensity Distribution } & 140\end{array}$ 
$3.7 \quad$ T-MATRIX SOLUTION FOR THE SPHERE 143

$\begin{array}{lll}\text { 3.7.1 Diagonalization of the Matrix Equations } & 144\end{array}$

3.7.2 Internal Field Expansion Coefficients 149

3.7.3 Scattered Field Expansion Coefficients 149

3.7.4 Comparison with Separation-of-Variables Solution 150

$\begin{array}{lll}3.8 & \text { SAMPLE COMPUTER PROGRAM } & 154\end{array}$

$\begin{array}{ll}\text { REFERENCES } & 184\end{array}$

\author{
Chapter 4 \\ SCATTERING BY A SPHERE
}

4.1 SEPARATION-OF-VARIABLES SOLUTION 188

$\begin{array}{lll}4.1 .1 & \text { Internal Field } & 190\end{array}$

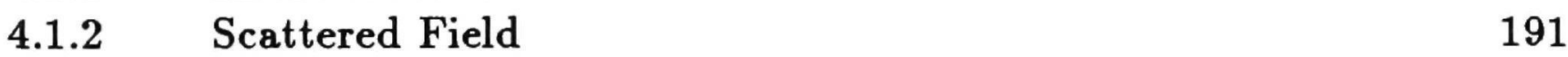

4.1.3 Scattered Intensity and Efficiencies 192

4.2 NUMERICAL IMPLEMENTATION 194

$\begin{array}{lll}\text { 4.2.1 Computer Program Description } & 194\end{array}$

4.2.2 Computational Procedures and Convergence Considerations 195

$\begin{array}{lll}\text { 4.3 ANGULAR SCATTERING } & 199\end{array}$

$\begin{array}{lll}\text { 4.3.1 Scattering Over a Plane } & 199\end{array}$

\begin{tabular}{ll} 
4.3.2 & Scattering in All Directions \\
\hline
\end{tabular}

$\begin{array}{ll}\text { 4.3.3 Scattering Matrix } & 205\end{array}$

$\begin{array}{lll}4.4 & \text { SPECTRAL SCATTERING } & 209\end{array}$

$\begin{array}{lll}4.5 & \text { INTENSITY DISTRIBUTIONS } & 218\end{array}$

$\begin{array}{lll}\text { 4.5.1 Angle-Averaged Intensity } & 218\end{array}$

4.5.2 Surface Intensity 222

$\begin{array}{ll}\text { 4.5.3 Internal Intensity Distribution } & 228\end{array}$

4.5.4 External Intensity Distribution 231 
4.6 AUXILIARY COMPUTER PROGRAMS 236

4.6.1 Small-Particle Approximation 237

$\begin{array}{ll}\text { 4.6.2 Program Dimensions } & 242\end{array}$

4.7 SAMPLE COMPUTER PROGRAM 243

REFERENCES $\quad 253$

$\begin{array}{ll}\text { INDEX } & 257\end{array}$ 